\title{
PSYCHOGRAPHIC CONSTRUCTS AND CONSUMER PURCHASE INTENTION IN KENYAN CONTEXT
}

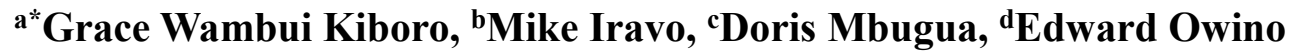 \\ ${ }^{a} \mathrm{PhD}$. Candidate, School of Business, Jomo Kenyatta University of Agriculture \\ and Technology \\ ${ }^{b}$ Professor, School of Business, Jomo Kenyatta University of Agriculture and \\ Technology \\ ${ }^{c}$ Lecturer, School of Business, Jomo Kenyatta University of Agriculture and \\ Technology \\ ${ }^{\mathrm{d}}$ Senior Lecturer, School of Business, KCA University \\ *Corresponding Author: *E-mail: kiborograce@gmail.com \\ P.O. Box 62000 - 00200 Nairobi, Kenya, Tel: +254722706607
}

\begin{abstract}
Competitiveness in the retail sector calls for an understanding of psychographic constructs and their potent drive of consumer purchase intention. The study examined psychographic constructs in terms of the effect of personality on consumer purchase intention in supermarkets and the effect of lifestyle on consumer purchase intention in supermarkets in Nairobi, Kenya. The study was grounded on Freud's theory of personality and social learning theory of consumer behaviour. Anchoring on a positivist philosophy, a descriptive cross-sectional survey was employed in studying 48 supermarkets. Using quota sampling, a final sample of 384 consumers was drawn from 48 anchor supermarkets under study. Data from the validated questionnaire was subjected to descriptive statistical analysis and multivariate regression analysis. Both personality and lifestyle had a positive and significant effect on consumer purchase intention and therefore the effect of psychographic constructs on consumer purchase intention was significant and positive. The larger effect size of lifestyle meant supermarket managers should pay more attention to attributes of consumer lifestyle.
\end{abstract}

KEYWORDS: Psychographic factors, anchor supermarkets, purchase intention

\section{INTRODUCTION}

Prior to the year 1916, supermarkets only existed in developed nations with little or no evidence of this form of retailing in developing countries. Increased global liberalization opened enormous opportunities for the expansion of the supermarket business (Lawrence \& Dixon, 2015). Berdegue and Reardon (2016) observed that in more recent times, consumers purchase trends have changed such that more consumers are purchasing from supermarkets rather than small grocery stores in both developed and developing nations. In Latin America the retail share of market grew from $10-20 \%$ in 1990 to $50 \%-60 \%$ in 
the year 2000 (Corvalan et al., 2017).

The stiffening rivalry amongst leading global retailers including; Whole Foods Market, Target, Carrefour and Wal-Mart led the supermarkets to venture into fast-expanding markets (FEM) such as China, Singapore and Japan. The FEM were attractive because of their rapid growth which provided opportunities for speedy financial growth for the retailers (Jewell, 2016). For example, Walmart from America merged with Massmart in South Africa, United Kingdom's Pound stretcher entered Zambia while Carrefour from France came to Kenya to increase their chances for growth (das Nair, 2018). Retailers, including anchor tenants (key supermarkets in shopping malls) in developed countries have been struggling to attract consumers to shop from their stores. However, in Africa, shopping malls are generally transforming local economies by riding on strong anchors retailers (Birkner, 2015). For instance, Carrefour, a leading retailer from France opened supermarkets in Egypt and Kenya where they anticipated fast growth since the retail industry was not fully developed (das Nair, 2018). These supermarket operators have strategically positioned themselves in shopping malls, to attract more consumer traffic for a competitive edge over their rivals.

However, for sustainable competitive advantage, it is imperative for supermarkets to know the satisfiers that make consumers want to buy from them and not from their rivals because retailers make their profits from the money paid by consumers who patronize their stores (Hussain \& Ali, 2015). When retailers understand the psychography of consumers, they are in a better position to serve them better by selling products and services these consumers associate with. For instance, excitable personalities will be attracted to elaborate designs and bright colours of the supermarket while reserved individuals will prefer modest designs and cool colours (Du Preez et al., 2018). Sociable consumers will want to engage with other shoppers and supermarket staff during their shopping. This requires the retailer to ensure they employ knowledgeable, courteous and friendly staff and a platform where consumers can interact with each other and the retailer such as social media or on the shop floor (Chu \& Sung, 2015). Word of mouth affects the decision to buy or not to buy from a retailer. Adventurous shoppers try out new products while inflexible consumers prefer to purchase products they know well thereby avoiding financial risk-taking (LeVine, 2018). Retailers must ensure their offering take care of consumers desiring different lifestyles. Hedonic shoppers can be attracted to a supermarket through creative displays that entice them to purchase. However, utilitarian consumers should be furnished with enough information to help them make conscious decisions to purchase from the store (Rezvani, Jansson, \& Bengtsson, 2018).

Consumers' psychographic factors comprise of their interests, opinions and attitudes which are seen in their hobbies, spending habits and values (Meredith \& 2017). It is necessary for retailers to understand their consumers' lifestyles so as to provide suitable offerings and ambience in their supermarkets (Lee \& Wu, 2017)). For example, upper class consumers have interest in premium brands such as expensive perfumes, groceries 
Print ISSN: 2053-4043(Print), Online ISSN: 2053-4051(Online)

and household goods which they buy from high-end stores that fit with their lavish lifestyle. Retailers should target such consumers with interesting promotions such as visits to exclusive tourist sites in cruises that suit their hobbies (Kendra, 2019).

Cutthroat competition amongst retailers has been on the rise and this challenge requires managers to outwit their rivals in attracting consumers to their supermarkets. Thus, the need for retailers to understand psychographic constructs that attract consumers to buy from particular supermarkets and not others. It is necessary for supermarkets to adopt strategies that are customer centric to successfully sway consumers to shop from their stores as opposed to those of their competitors (Mbugua et al., 2015). Retailers can only do this when they understand the factors that influence consumers to buy from a particular store (Narayan \& Chandra, 2015). However, these supermarkets are facing challenges in attracting a bigger consumer base from their rivals. This can be attributed to lack of adequate and relevant studies on psychographic determinants of consumer purchase behaviour in Kenya. Additionally, most studies on the subject have been conducted in developed countries like America and Europe making their application difficult. Moreover, there are limited studies on anchor supermarkets and yet this is a fast-growing retail trend in Kenya. The study, therefore, sought to answer the question, 'what is the influence of psychographic constructs?' The study sought to address two research objectives; the effect of personality on consumer purchase intention in supermarkets and the effect of lifestyle on consumer purchase intention in supermarkets in Nairobi, Kenya. The study contributes to theory and knowledge in the area of retail management and enablers of consumer purchase intention. The study provides invaluable insights to retailers on what attracts consumers to their supermarkets and hence improved business performance.

\section{LITERATURE REVIEW}

The reviewed literature presents theories that underpin the study and the empirical review examines studies by other researchers on what comprises the psychological construct. Two theories referred to in this study were; Freud's theory of personality by Freud (1923) and Social Learning Theory of consumer behavior proposed by Bandura (1969). The theories support the relationship between purchase intention dependent varaible with psychographic and psycholocial factors as independent variables. Social learning theory is concerned with social behaviour and the learning process (Bandura, 1969). This implies that consumers acquire new behaviour through observing and copying friends, workmates and family. Learning takes place continuously through reinforcement (Skinner, 1969). Thus, consumers can learn which brands to purchase by observing shopping behaviour of other shoppers. Someone is motivated to identify with another person if the latter possess beliefs, behaviours, values, and attitudes which one would like to have (Bandura, 1977). This view is supported by studies carried out on social interactions of consumers. Wang and $\mathrm{Yu}$ (2017) in support of this view established that consumers decide to purchase from certain supermarkets through interacting with retailer employees and other buyers. 
Print ISSN: 2053-4043(Print), Online ISSN: 2053-4051(Online)

Retailers need to create social platforms where consumers can interact with each other and share experiences. Good word of mouth about a retailer will encourage other consumers to buy from them. Television commercials were good socialization agents for dissemination of product information. He claimed that by observation and simulation of television advertising, consumers got to know how to ascribe social meaning to brands (Bandura, 1977). Social learning through advertising appealed to the irrational buying tendency of consumers affecting them to make choices based on impulse. In support of the social learning theory, scholars contended that family was responsible for teaching individuals like children to become consumers (Wackman, Ward, \& Wartella, 1977).

Proponents of social learning theory postulate that consumers observe the buying behaviour of other shoppers and learnt to emulate their purchasing behaviour (Wang \& Yu, 2017). For example, children learnt to purchase from retailers where their parents shopped frequently or recommended. Retailers must ensure they leave a lasting impression on consumers who shop in their stores to encourage them to recommend their stores to other shoppers. Also, consumers who interact socially through commercial sites on the internet make purchase decisions after observing and learning purchase actions of other consumers. Retailers should effectively use social media interactions to bring in new buyers, in addition to those who frequently purchased from their stores. SLT was supported further by scholars arguing that consumers who observe the behaviour of other consumers during experiential campaigns get influenced to make similar purchase decisions (Alavi, Rezaei, Valaei, \& Wan Ismail, 2016). Retailers should provide memorable shopping experience which when shared by consumers in social networks will attract more shoppers to their supermarkets (Tajvidi, Richard, Wang, \& Hajli, 2018). This theory provides useful input to the independent variable on consumer lifestyle and the indicators that this research uses to operationalize consumer way of life such as adventure, style, status and hobbies. These insights provide a great opportunity for supermarkets to advertise to consumers, parents or opinion leaders to influence other consumers to purchase from their stores.

Studies by Freud adopted psychodynamic tradition whose key tenet was that actions are due to biological factors as opposed to individual reasoning, or stimuli from the environment (Freud, 1923). This outlook posited that somebody's behaviour is impacted by biological elements by way of drives or instinctive influences that operate outside the conscious thought of an individual. He recognized three aspects of the mind known as the superego, the ego and the id which he hypothesized shaped an individual's personality. The ego was associated with the conscious mind and functions under the reality principle and comprised of feelings, thoughts, lifestyles and memories. He further maintained that the ego was an internal consciousness and drive that executed ones personality (Freud, 1923). This would imply that consumers make both conscious and unconscious decisions to purchase from a retailer. As such, retailers must creatively design emotional and rational advertisements regarding their stores to be able to impact consumers to buy from them. The superego was connected to societal forces and was responsible for the ethical 
and moral aspects of a person. This would prompt a person to purchase from retailers who supported social missions. Backing Freud's theory, researchers suggested that retailers ought to provide products that helped consumers fulfil their moral and social obligations like environmentally friendly products (Nuttavuthisit \& Thøgersen, 2017). This way, they would increase chances of such consumers buying from their supermarkets.

The id comprises of all the biological elements of personality that are inherited. The id is impulsive and is responsible for the unconscious behaviour of a person making one respond straightaway to drives. It wants instant gratification for its wishful desires and needs irrespective of the outcome. Freud's theory on id pleasure principle implies that individual consumers will tend to purchase on impulse based on various drives that prompt them. For example, consumers often spontaneously or compulsively from supermarkets (Udo-Imeh, 2015). There are a group of risk-averse consumers who are scared of new brands such as retailers or products (Kovacs \& David, 2016). These consumers would, therefore, prefer to buy only products they know or from retailers they regularly purchase from. These consumers are not ready to take chances and are sceptical of new offerings meeting their expectations. Inflexibility is a typical personality trait observed in consumers who only buy brands they know (He, Zhan, \& Hu, 2018). Retailers must sample such consumers to enable them experience new brands and introduce variants under the same brand names to ensure consumers continue to purchase from them. Other consumers are not afraid to take risks and they readily shop for new brands. Retailers should provide new exciting brands and innovations that are popular locally and globally to attract this set of consumers.

Retailers can apply Freud's contribution to create brand appeals towards fantasy and fun (Lowrie, 2018). A pleasant shopping experience will impulsively trigger consumers to purchase from such a retailer. The idea that irrational forces drive unconscious consumer behaviour can be maximized by retailers in their advertising campaigns on products and services (Neese, Foxx, \& Eppler, 2018). For example, retailers can entice fun-loving consumers to buy from their stores by using emotional advertising campaigns. Additionally, retailers can apply Freud's contribution by creating a brand image that appeals to consumers' fantasy, deep desire, friendliness or some escape from life. This can be done through offering a memorable shopping encounter to inspire consumers to equate the retailer brand with a personal desire enticing them to shop from that retailer. This model provides useful contribution to the variable of consumer personality and the indicators the study uses to operationalize the variable such as consumer innovativeness, loyalty to favourable retailer and social disposition.

Empirical literature on psychological constructs is built around two factors; consumer personality and consumer lifestyle. Personality is defined by Corr and Matthews (2009), as the characteristic sets of behaviors, cognitions, and emotional patterns that evolve from biological and environmental factors. Freud (1923) recognized three aspects of the mind known as the superego, the ego and the id which he hypothesized shaped an individual's 
personality. Njigua (2018) demonstrated that personality has a significant positive influence on consumer's decision to buy. This was especially true when the consumer was able to identify himself/herself with the products and services that signaled a store image that resonated with him/her

Innovative consumers have an inborn tendency to look for the latest experience or information. As a result, they are attracted to different or new retailers in search of the newest innovations of products or services. These consumers see value from a creative retailer who is perceived to offer what they desire and so they visit the supermarket regularly to buy these novelties (Lin, 2016). Innovative consumers were usually willing to buy new inventions available from retailers (Hussain \& Ali, 2015). It is therefore important for retailers to effectively communicate these novel offerings to consumers, for example, through social media. This awareness will sway creative consumers to visit their stores frequently for the latest items such as fashion items. Consumers who were riskaverse were people who regularly chose to buy from particular retailers who they were confident about (Jones et al., 2015). Even in future, these consumers indicated they planned to frequently purchase from these stores. Risk averse consumers tended to regularly buy from the retailer they knew well. This helped these consumers avoid risks associated with purchase where they might be unable to return a product exposing them to financial risk (Muturi, Omwenga, \& Owino, 2018). These consumers patronized the same stores and retailers used loyalty schemes enabling consumers to accumulate points that could be redeemed for products in the future. This kept these consumers visiting the stores repeatedly. Hedonic shoppers are always looking for fun and adventurous experience from the retailers they patronize. Consequently, a supermarket that provides opportunity for adventure and recreation positively attracts these consumers to frequently purchase from them for the fun of it (Alavi et al., 2016). These consumers are often attracted to retail stores located in malls where there are numerous entertainment areas to indulge in while shopping. The findings indicated that although style orientation by shoppers was assumed to be a personality attribute, it was not a precursor to lifestyle relating to mall atmosphere. However, fashion orientation played a moderating role in the association between patronage intentions and opinion about quality of offerings and the response of hedonic shoppers. Hedonic shoppers relish the shopping process since it gives them enjoyment and fun (Kesari \& Atulkar, 2016). These consumers are attracted to retail stores that provide entertainment and exploration.

Consumer lifestyle is described by Sathish and Rajamohan (2012) as a distinctive mode of behaviour centered around activities, interests, opinions, attitudes and demographic characteristics distinguishing one segment of a population from another. The consumer's lifestyle is seen as the sum of his interactions with his environment. Lifestyle studies are a component of the broader behavioural construct called psychographics. Sathish and Rajamohan (2012) present lifestyle marketing is a process of establishing relationships between products offered in the market and targeted lifestyle groups. So that consumers interested in fashions and newest trends visit supermarkets to look for new innovations 
Print ISSN: 2053-4043(Print), Online ISSN: 2053-4051(Online)

which increases their chances of buying from the retailer (Khare, 2016). As a consumer walks leisurely and casually looking at store merchandise, they socialize with other consumers or staff about the products. In most cases, when they find items of interest and if they have the money to buy, they end up purchasing products on impulse. Consumer opinion about their status increases their intention to shop from high-end stores such as those located in malls which they view as matching their social class (Wang \& Yu, 2017). This is because these consumers highly regard the opinion of others and especially the affirmation from people of their social group with whom they share information about the retailers they shop from.

Mohiuddin (2018) unearths the significance of marketing managers appreciating the buying behaviour of female customers because their purchase decisions are centred on their lifestyle in terms of their social status, likeness and ongoing fashion trend. Rani (2014) presents various factors that affect the lifestyle of consumers including; demographic elements, aims, beliefs, values, the environment of the consumer. Krishnan (2011) concluded that consumers often choose products, services and activities over others because they are associated with a certain lifestyle. For instance consumer activities such as browsing for self-entertainment increases their chances of purchasing from a store (Lee \& Wu, 2017). There was a significant correlation between browsing by consumers and in store purchasing activity (Blazquez, Zhang, Boardman, \& Henninger, 2019). This implies that retailers should find strategies that encourage browsing as a great way to increase purchasing from their stores. Retailers should provide a conducive environment where consumers are able to spend more time inside experiencing their merchandise to increase opportunities for purchase.

\section{RESEARCH METHODOLOGY}

The research methodology adopted anchored on a positivist philosophy, that Saunders, Lewis and Thornhill (2016) describe as an inferential method that requires a researcher to be independent of the study, test hypotheses and draw deductions based on the results of the hypothesis test. In line with the research philosophy, descriptive research design was used to provide answers to the; who, where, when, what and how questions regarding diverse components under this study (Burns \& Veeck, 2017). This kind of descriptive cross-sectional investigation has been adopted by a number of researchers in numerous areas as well as that of purchase intention (Gichunge, Ernest, \& Bonuke, 2017). Further, this research design was considered to be suitable due to its adaptability, admissibility of research instruments; and its suitability when gathering information from a big group of respondents within a fairly little time span. The population in this study consisted of anchor supermarkets located in shopping malls in Nairobi Metropolitan (Nairobi City County, Machakos County, Kiambu County and Kajiado County). An anchor supermarket is a prominent retailer used to attract consumers to the shopping mall and in this way brings business for other traders in the mall premises (Jewell, 2016). This research applied quota sampling technique where the population was divided into subgroups (quotas) and 
Print ISSN: 2053-4043(Print), Online ISSN: 2053-4051(Online)

subsequently allowed for selection of sample members using convenience methods. The prospective respondents were such that the first respondent was picked at random and thereafter every 10th adult consumer, above the age of eighteen years, entering the anchor supermarket. The questionnaire was subjected to a pilot test to assess its content validity and face validity. Sekaran et al. (2016) posits that content validity is the range within which the measuring device will provide sufficient coverage of research questions guiding this study. The questionnaire was administered to three marketing experts for their expert opinion on the adequacy of the content. Muturi et al. (2018) citing Abbott and McKinney (2013) add that face validity represents a non-statistical evaluation by the researcher on if the test carried out in the study will appear to be valid or not. Their feedback was used to improve the research instruments, remove vague and double barrelled questions as suggested by Cooper and Schindler (2014). The final survey instrument was then considered valid. Reliability of the instrument was tested for by use of Cronbach alpha check as proposed by Akeem (2015). The items in the instrument resulted in an overall Cronbach alpha $=0.820$. Consistent with Owino, Nyaribo and Wadawi (2017) position, an overall alpha $\geq 0.7$ of the instrument was interpreted to mean the instrument is reliable, the study instrument was therefore considered reliable. Two statistical tests were performed; descriptive statistical test and multivariate regression analysis. Descriptive statistics was used in profiling the respondents along demographic parameters and measures of central tendency including; frequency distribution, crosstabulation, mean score analysis, standard deviation, and correlation analysis were applied. Multiple regression analysis was used the testing of research hypothesis. A significant relationship was to exist whenever a coefficient had a sig. value less than 0.05 (p-value $\leq$ 0.05). The data was subjected to four assumptions (multivariate normality test, multicollinearity test, linearity test and homoscedasticity test) of regression with no violation observed.

\section{Effect of Psychographic Constructs on Consumer Purchase Intention}

Regression analysis was applied in examining the effect predictor variable (psychographic construct) on the outcome variable (consumer purchase intention) in supermarkets in Nairobi, Kenya. The psychographic construct was abstracted in terms of a two-factor model comprising of consumer personality and consumer lifestyle. Assuming a linear relationship between the psychographic constructs and purchase intention the study used Ordinary Least Square (OLS) technique of approximation to extract a best fit line of regression. The following hypothesis was tested;

$\mathrm{H}_{01}$ : Personality has no significant effect on consumer purchase intention in supermarkets in Nairobi.

$\mathrm{H}_{02}$ : Lifestyle has no significant effect on consumer purchase intention in supermarkets in Nairobi. 
Print ISSN: 2053-4043(Print), Online ISSN: 2053-4051(Online)

In an initial test, the study sought to determine the direct influence of each factor followed by an overall examination of the impact of psychographic construct on consumer purchase intention. Using OLS method personality was regressed against consumer purchase intention. The resulting coefficient of determination $\left(\mathrm{R}^{2}\right)$ of the model $=0.131$, the ANOVA statistics related to personality was significant ( sig. value $=0.000$ ) implying the model predicted by personality was significant at explaining the relationship between personality and purchase intention connection. Table 1 denotes that the coefficient of personality was significant ( $p$-value $=0.000, \beta_{4}=0.302$ ). The study, therefore, interpreted the results to mean that the linear connection between personality and purchase intention was significant.

Table 1: Coefficients of Personality

\begin{tabular}{|c|c|c|c|c|c|c|c|}
\hline \multirow[t]{2}{*}{ Model } & \multicolumn{2}{|c|}{$\begin{array}{l}\text { Unstandardized } \\
\text { Coefficients }\end{array}$} & \multirow{2}{*}{$\begin{array}{l}\text { Standardized } \\
\text { Coefficients } \\
\text { Beta }\end{array}$} & \multirow[t]{2}{*}{$\mathrm{t}$} & \multirow[t]{2}{*}{ Sig. } & \multicolumn{2}{|c|}{$\begin{array}{c}95.0 \% \\
\text { Confidence } \\
\text { Interval for B }\end{array}$} \\
\hline & B & $\begin{array}{l}\text { Std. } \\
\text { Error }\end{array}$ & & & & $\begin{array}{l}\text { Lower } \\
\text { Bound }\end{array}$ & $\begin{array}{l}\text { Upper } \\
\text { Bound }\end{array}$ \\
\hline (Constant) & 2.736 & .158 & & 17.270 & .000 & 2.424 & 3.047 \\
\hline Personality & 0.302 & .042 & .361 & 7.167 & .000 & .219 & 0.385 \\
\hline
\end{tabular}

a. Dependent Variable: Purchase Intention

In the second test the effect of lifestyle on consumer purchase intention was tested. The model summary shows the coefficient of determination $\left(\mathrm{R}^{2}\right)$ for the model was 0.583 , this indicated that the model predicted by lifestyle under the direct effect provided a good fit (Liu, Lee, \& Jordan, 2016). Resulting from the ANOVA statistics the model had a significant value $=0.000$ which implied that the model predicted by lifestyle had a significant linear relationship with purchase intention. The coefficient of lifestyle in Table 2 was significant (with $\mathrm{p}$-value $=0.000, \beta_{2}=0.911$ ). This suggested that lifestyle had a significant effect on purchase intention on a liner a relationship with purchase intention.

Table 2: Coefficient of Lifestyle

\begin{tabular}{|c|c|c|c|c|c|c|c|}
\hline \multirow[b]{2}{*}{ Model } & \multicolumn{2}{|c|}{$\begin{array}{l}\text { Unstandardized } \\
\text { Coefficients }\end{array}$} & \multirow{2}{*}{$\begin{array}{l}\text { Standardized } \\
\text { Coefficients } \\
\text { Beta }\end{array}$} & \multirow[b]{2}{*}{$\mathrm{t}$} & \multirow[b]{2}{*}{ Sig. } & \multicolumn{2}{|c|}{$\begin{array}{l}95.0 \% \text { Confidence } \\
\text { Interval for B }\end{array}$} \\
\hline & B & $\begin{array}{l}\text { Std. } \\
\text { Error }\end{array}$ & & & & $\begin{array}{l}\text { Lower } \\
\text { Bound }\end{array}$ & $\begin{array}{l}\text { Upper } \\
\text { Bound }\end{array}$ \\
\hline $1 \quad$ (Constant) & .531 & .154 & & 3.459 & .001 & .229 & .833 \\
\hline Lifestyle & .911 & .042 & .763 & 21.891 & .000 & .830 & .993 \\
\hline
\end{tabular}

a. Dependent Variable: Purchase Intention 


\section{Psychographic Constructs and Consumer Purchase Intention}

The combined effect of personality and lifestyle (psychographic construct) on consumer purchase intention was tested. The combined effect was tested using regression analysis as modelled in equation 1 below.

$$
\mathrm{Y}=\alpha_{3}+\beta_{1} \mathrm{X}_{1}+\beta_{2} \mathrm{X}_{2}+\varepsilon_{3} \quad \text { equation (1) }
$$

In equation ( 1$), \mathrm{Y}=$ consumer purchase intention, $\alpha_{3}=$ constant, $\mathrm{X}_{1}=$ personality, $\mathrm{X}_{2}=$ lifestyle, $\varepsilon_{3}=$ error term related to the regression model, $\beta_{1}=$ beta parameters of personality and $\beta_{2}=$ beta parameters of the lifestyle. The model summary of the two psychographic constructs shows the combined model had an $\mathrm{R}^{2}=0.596$. The model predicted by psychographic factors under the combined effect therefore provided a good fit (Liu et al., 2016). The ANOVA statistics related to psychographic construct demonstrated that the combined model had a significant value $=0.000$. This meant that the model predicted by psychographic factors (personality and lifestyle) had a significant linear relationship with purchase intention relationship.

The coefficient of personality was significant (with $p$-value $=0.001, \beta_{1}=0.100$ ) and therefore the study rejected $\mathrm{H}_{01}$ at $5 \%$ level, and interpreted the results to mean that personality had a significant effect on consumer purchase intention in supermarkets in Nairobi, Kenya. The coefficient of consumer lifestyle was significant (with a sig. value = $0.000, \beta_{2}=0.866$ ) and therefore the study rejected $\mathrm{H}_{02}$ at $5 \%$ level, and interpreted the results to mean that lifestyle had a significant impact on consumer purchase intention in supermarkets in Nairobi, Kenya.

Table 3: Coefficients of Psychographic Factors

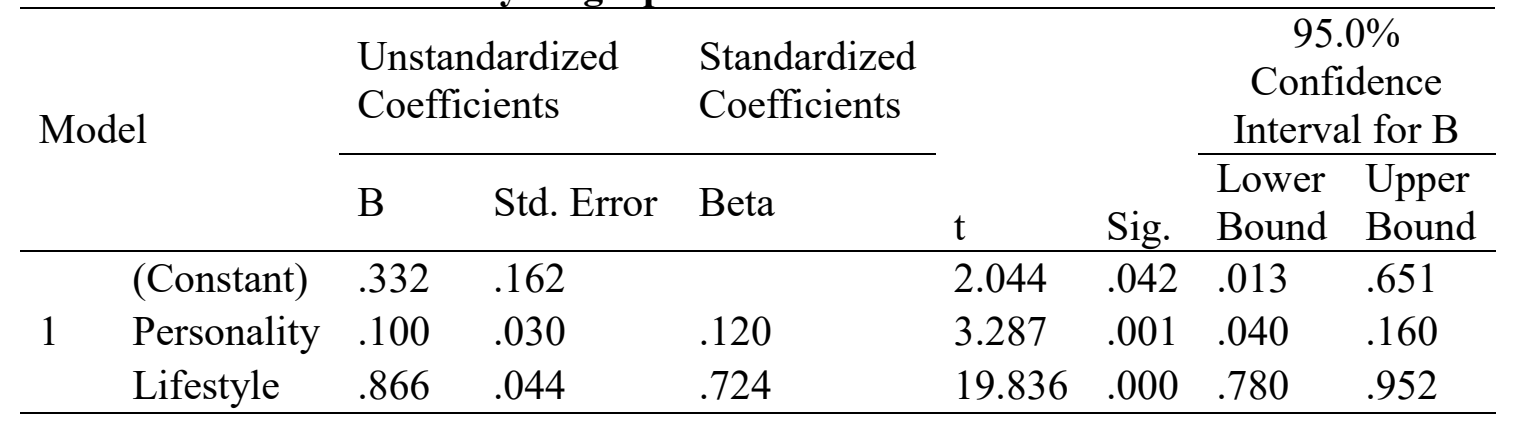

a. Dependent Variable: Purchase Intention

From Table 3, the resulting coefficients were used in derivation of the fitted model based on the combined effect as shown in equation (2);

$$
\mathrm{Y}=0.332+0.100 \mathrm{X}_{1}+0.886 \mathrm{X}_{2}
$$

equation (2) 
Print ISSN: 2053-4043(Print), Online ISSN: 2053-4051(Online)

From the fitted equation (2), $\mathrm{Y}=$ purchase intention, $0.332=$ constant, $\mathrm{X}_{1}=$ consumer personality, $\mathrm{X}_{2}=$ consumer lifestyle. The value of intercept of 0.332 indicates in the absence of psychological constructs, consumers will engage in very little purchase. This conforms to the Howard and Sheth consumer buyer behaviour model that postulates that there are endogenous and exogenous constructs that trigger the consumer purchase intention (Howard \& Sheth, 1969). Consumer lifestyle had the highest effect on purchase intention, where a unit variation in consumer lifestyle would result in a $86.6 \%$ positive variation in purchase intention. Consumer personality had the second highest effect on purchase intention, where a unit variation in consumer personality would results in a $10.0 \%$ positive variation in purchase intention. In general, the results show that psychographic constructs (in terms of lifestyle and personality) had a significant and positive effect on consumer purchase intention.

\section{DISCUSSION ON FINDINGS}

The first research objective sought to evaluate the effect of lifestyle on consumer purchase intention in supermarkets in Nairobi, Kenya. The research determined that lifestyle had a significant effect on consumer purchase intention in supermarkets in Nairobi, Kenya. Using mean score analysis, the variables with the highest mean for lifestyle were; consumer liking to shop in the selected supermarket $(m e a n=4.14)$, followed the supermarket being consumers first choice when they want to shop (mean=3.93), consumer preference of buying from the supermarket than any other (mean=3.80) and consumer preference of buying trendy/stylish/fashionable products from the supermarket (mean=3.56). Backing these findings Khare (2016) observed that consumers interested in fashions and newest trends visit their favorite supermarkets to look out for new innovations in sync with their social standing which increases their chances of buying from the retailer. Tantanatewin et al. (2016) and Sundar et al. (2017) revealed that logo colour attracted consumers to shop from preferred retailers. Contrary to other findings that indicate consumers take time to browse supermarkets prior to making a purchase (Lee et al., 2017), the respondents in this study disagreed that they spend time browsing a supermarket. These outcomes point to a group of consumers who are loyal to a particular supermarket as earlier noted by Muturi et al. (2018). This is the retailer who is top of mind whenever these consumers want to go shopping.

Under the second research objective, the study established that personality had a significant effect on consumer purchase intention in supermarkets in Nairobi, Kenya. The mean score analysis shows that the variables which best described consumer personality were; shopping in a supermarket out of emotions (mean score $=3.85$ ), shopping in a supermarket for fun (means score $=3.82$ ) and purchasing in the supermarket because it allowed the shopper to socialize (mean score $=3.80$ ). The mean score of personality was 3.58 , which meant most of the consumers agreed that personality influenced their purchase intentions. This outcome was consistent with Alavi et al. (2016) who poised that most shoppers including hedonic shoppers are always looking for fun and adventurous 
experience from the retailers they patronize. In support for consumers preferring stores they knew well, Jones et al. (2015) found that consumers who were risk averse preferred to buy from supermarkets they knew well. Contrary to what Muturi et al. (2018) maintained about consumers being loyal to a retailer to avoid financial loss, the fact that consumers shopped from other different stores shows that financial risk averseness does not always make a consumer buy from a specific supermarket. In agreement Lee et al. (2017) established that as consumer socialize with other consumers or staff about the products they are able to make informed decisions on what to buy.

\section{CONCLUSION, IMPLICATION AND RECOMMENDATION}

It was concluded that psychographic factors in terms of lifestyle related factors and consumer personality related factors both affect the consumer purchase intention. Lifestyle had a larger effect size on consumer purchase intention amongst shoppers in Kenyan supermarkets. Focusing on lifestyle, the research concluded that the main determinants of lifestyle were; recommendation from friends, shopping was a parttime/hobby and consumers are attracted by the supermarket colours. Other lifestyle variables were; consumer liking to shop in the selected supermarket, the supermarket being consumers first choice when they want to shop, consumer preference of buying from the supermarket than any other and consumer preference of buying trendy/stylish/fashionable products from the supermarket. It was concluded that key descriptors of personality related variables were; consumers shopping in a supermarket out of emotions, shopping in a supermarket for fun and purchasing in the supermarket because it allowed the shopper to socialize.

The study recommends that marketers in supermarkets should undertake regular audits to understand the changing consumer lifestyle. The aspect of consumer lifestyle that should be monitored closely include; word of mouth recommendation from friends, consumer tendency to shop as a part-time/hobby, attractiveness of supermarket colours, ability of supermarkets to stock trendy/stylish/fashionable products and; ability of supermarket to give a reflection of who the consumer is (identity). Stemming from this observation, the study recommends that managers must strive to create a supermarket brand identity or brand persona that resonates with the lifestyle of the shoppers. Stemming from the personality related discussion, the study recommends that supermarkets should adopt the use of emotional appeals in their marketing communication strategies because of its proven strong effect in influencing consumer purchase intention.

The research focused on psychographic constructs and their impact on consumer purchase intention. However, consumer buyer behaviour theories reveal other constructs that define consumer behaviour. The study recommends that further academic effort should be aimed at identifying the influence of these additional factors on consumer purchase intention in a supermarket context. 


\section{References}

Alavi, S. A., Rezaei, S., Valaei, N., \& Wan Ismail, W. K. (2016). Examining shopping mall consumer decision-making styles, satisfaction and purchase intention. The International Review of Retail, Distribution and Consumer Research, 26(3), 272303.

Akeem, B.O. (2015) Principles and methods of validity and reliability testing of questionnaires used in social and health science researches, Nigerian Postgraduate Medical Journal, 22 (4), 195-201.

Bandura, A. (1969). Principles of behavior modification.

Bandura, A. (1977). Social learning theory general learning press. New York.

Berdegué, J. A., \& Reardon, T. (2016). Impacts of the supermarket revolution and the policy and strategic responses Creating Food Futures (pp. 149-161): Routledge.

Birkner, C. (2015). Music: The unsung hero of advertising. Paper presented at the American Marketing Association.

Blazquez, M., Zhang, T., Boardman, R., \& Henninger, C. E. (2019). Exploring the Effects of Social Commerce on Consumers' Browsing Motivations and Purchase Intentions in the UK Fashion Industry Social Commerce (pp. 99-115): Springer.

Burns, A. C., \& Veeck, A. (2017). Marketing research: Pearson.

Chu, S.C., \& Sung, Y. (2015). Using a consumer socialization framework to understand electronic word-of-mouth (eWOM) group membership among brand followers on Twitter. Electronic Commerce Research and Applications, 14(4), 251-260.

Corr, P. J., \& Matthews, G. (Eds.) (2009). The Cambridge handbook of personality psychology (pp. 748-763). New York: Cambridge University Press.

Corvalan, C., Garmendia, M., Jones-Smith, J., Lutter, C., Miranda, J., Pedraza, L., . . . Stein, A. (2017). Nutrition status of children in Latin America. Obesity Reviews, $18,7-18$.

das Nair, R. (2018). The internationalisation of supermarkets and the nature of competitive rivalry in retailing in southern Africa. Development Southern Africa, 35(3), 315-333.

Du Preez, M., Dreyer, H., Botha, E., van der Colff, N., Coelho, D. C., \& Pretorius, M. (2018). Older female consumers' clothing quality perception: expectations and performance. Journal of Consumer Sciences, 46.

Fairchild, J. (2002). Instrument reliability and validity: Introductory concepts and measures. Philadelphia: James Madison University.

Freud, S. (1923). The ego and the id. Standard Edition, 19: London: Hogarth Press.

Gageler, L., \& van der Schee, J. (2016). Product Placement on Social Media: a study on how Generation Y's brand perception and purchase intention are influenced.

Gichunge, N. C., Ernest, S., \& Bonuke, R. (2017). The moderating effect of store image on the indirect relationship between socio-sensory experience and the purchase intention via social value.

He, X., Zhan, W., \& Hu, Y. (2018). Consumer purchase intention of electric vehicles in China: The roles of perception and personality. Journal of Cleaner Production, 204, 1060-1069. 
Howard, J. A., \& Sheth, J. N. (1969). The theory of buyer behavior. New York, 63.

Hussain, R., \& Ali, M. (2015). Effect of store atmosphere on consumer purchase intention. International Journal of Marketing Studies, 7(2).

Jewell, N. (2016). Shopping malls and public space in modern China: Routledge.

Jones, M. A., Reynolds, K. E., Arnold, M. J., Gabler, C. B., Gillison, S. T., \& Landers, V. M. (2015). Exploring consumers' attitude towards relationship marketing. Journal of Services Marketing, 29(3), 188-199.

Kariuki, L. W. (2018). Factors Influencing Performance Of Micro And Small Enterprises In Kenya A Case of Kiambu County, Kenya. Kca University.

Kendra, C. (2019). Updating Maslows Hierarchy of Needs. Retrieved October 2019, from https://verywellmind.com

Kesari, B., \& Atulkar, S. (2016). Satisfaction of mall shoppers: A study on perceived utilitarian and hedonic shopping values. Journal of Retailing and Consumer Services, 31, 22-31.

Khare, A. (2016). Consumer shopping styles and online shopping: An empirical study of Indian consumers. Journal of Global Marketing, 29(1), 40-53.

Kovacs, L., \& David, S. (2016). Fraud risk in electronic payment transactions. Journal of Money Laundering Control, 19(2), 148-157.

Krishnan, J. (2011). Lifestyle-A tool for understanding buyer behavior. International Journal of Economics and Management, 5(1), 283-298.

Lawrence, G., \& Dixon, J. (2015). The political economy of agri-food: Supermarkets. Handbook of the International Political Economy of Agriculture and Food, 213.

Lee, C.-H., \& Wu, J. J. (2017). Consumer online flow experience: the relationship between utilitarian and hedonic value, satisfaction and unplanned purchase. Industrial Management \& Data Systems, 117(10), 2452-2467.

LeVine, R. A. (2018). Culture, behavior, and personality: An introduction to the comparative study of psychosocial adaptation: Routledge.

Lin, C.-Y. (2016). Perceived convenience retailer innovativeness: how does it affect consumers? Management Decision, 54(4), 946-964.

Liu, Q., Lee, J., \& Jordan, M. (2016). A kernelized Stein discrepancy for goodness-of-fit tests. Paper presented at the International conference on machine learning.

Lowrie, A. (2018). The Shattered Brand Fantasy Understanding Branding in Higher Education (pp. 91-102): Springer.

Mbugua, D., Nyakundi, I., Mbobua, D. M., Alusa, D. K., Kimaru, J. W., Kinyua, C. W., . . Mamo, N. (2015). Market Orientation, Firm Characteristics, Dynamic Capabilities and Performance of Deposit Taking Savings and Credit Cooperative Societies in Kenya. Unpublished PhD Thesis, University of Nairobi, Kenya.

Meredith, A., \& (2017). How to Use Psychographics in Your Marketing: A Beginner's Guide. Georgetown University. Rio de Janeiro.

Mohiuddin, Z. A. (2018). Effect of Lifestyle on Consumer Decision Making: A Study of Women Consumer of Pakistan. Journal of Accounting, Business and Finance Research, 2(1), 12-15. 
Mugenda, O. M., \& Mugenda, A. G. (2013). Research methods: Quantitative and qualitative approaches. Nairobi: Razoma.

Muturi, F. M., Omwenga, J., \& Owino, E. (2018). Determinants of brand loyalty in leading supermarket chains in Kenya. JKUAT-COHRED.

Narayan, G., \& Chandra, R. (2015). Factors Affecting the Purchase of Food and Grocery Products from Modern Retail Stores: An Empirical Study. IUP Journal of Management Research, 14(2).

Neese, W. T., Foxx, W., \& Eppler, D. B. (2018). The influence of industry-specific personal characteristics on consumer reactions to domestic vs. foreign comparative advertising in the American automobile market. Cogent Business \& Management, 5(1), 1444329.

Nuttavuthisit, K., \& Thøgersen, J. (2017). The importance of consumer trust for the emergence of a market for green products: The case of organic food. Journal of Business Ethics, 140(2), 323-337.

Owino, E., Nyaribo, W.M. \& Wadawi J.K. (2017). Service Value Assessment in Emerging Chain Restaurants in Nairobi Kenya, Journal of Research in Marketing, 6(3)518-533.

Rani, P. (2014). Factors influencing consumer behaviour. International Journal of Current Research and Academic Review, 2(9), 52-61.

Razali, N. M., \& Wah, Y. B. (2011). Power comparisons of shapiro-wilk, kolmogorovsmirnov, lilliefors and anderson-darling tests. Journal of statistical modeling and analytics, 2(1), 21-33.

Rezvani, Z., Jansson, J., \& Bengtsson, M. (2018). Consumer motivations for sustainable consumption: The interaction of gain, normative and hedonic motivations on electric vehicle adoption. Business Strategy and the Environment, 27(8), 12721283.

Saunders, M., Lewis, P., \& Thornhill, A. (2016). Research Methods for Business Students. 289-299. Harlow, England: Prentice Hall. Seidel, Saskia, Corinne Blanquart and Verena Ehrler.

Sathish, S., \& Rajamohan, A. (2012). Consumer behaviour and lifestyle marketing. International Journal of Marketing, Financial Services \& Management Research, 1(10), 152-166.

Sekaran, U., \& Bougie, R. (2016). Research methods for business: A skill building approach. John Wiley \& Sons.

Skinner, B. F. (1969). Contingencies of reinforcement; a theorical analysis.

Tajvidi, M., Richard, M.-O., Wang, Y., \& Hajli, N. (2018). Brand co-creation through social commerce information sharing: The role of social media. Journal of Business Research.

Wackman, D. B., Ward, S., \& Wartella, E. (1977). How Children Learn to Buy: The Development of Consumer Information Processing.

Wang, Y., \& Yu, C. (2017). Social interaction-based consumer decision-making model in social commerce: The role of word of mouth and observational learning. International Journal of Information Management, 37(3), 179-189. 
British Journal of Marketing Studies

Vol. 8, Issue 2, pp.96-111, March 2020

Published by ECRTD- $U K$

Print ISSN: 2053-4043(Print), Online ISSN: 2053-4051(Online)

Zikmund, W., Babin, B., Carr, J., \& Griffin, M. (2013). Business Research Methods, 9th International Edition. South-Western Cengage Learning, Canada. 